\title{
PENGEMBANGAN PELAYANAN PUBLIK BERBASIS E-GOVERNMENT DALAM PROGRAM LAYANAN PERIZINAN ONLINE (LAPERON) DI DPMPTSP KABUPATEN BADUNG
}

\author{
Wismayanti ${ }^{1}$ \\ E-mail : wiwin.fisip@unud.ac.id \\ Purnamaningsih $^{2}$ \\ E-mail : ekapurnama@unud.ac.id
}

Fakultas Ilmu Sosial dan Ilmu Politik Universitas Udayana

\begin{abstract}
Advances in communication and information technology bring many changes to the general habits of society. Communication and information technology is now inseparable from people's lives in this era. With digitalization, people can disseminate and obtain information widely without requiring a long time. The benefits of this easy, cheap, and fast technology have in common with the concept of excellent public service which is the hope of the community. In public services, people want services that are easily accessible, do not incur a lot of costs, and also do not require a long time to receive public services. To provide excellent service in this era of rapid technological progress and the government can optimize the use of information and communication technology in governance, which is known as E-government. Through the development of public service innovations based on E-government, it is expected to be able to provide services that are in accordance with the principles of good governance, so as to improve service quality and community satisfaction. Dinas Penanaman Modal dan Pelayanan Terpadu Satu Pintu (DPMPTSP) of Badung Regency builds public service innovations called Layanan Perizinan Online (LAPERON). This study uses qualitative research methods through secondary data collection. The development of public services in the LAPERON application can be seen from the availability of LAPERON on the website and also the Mobile Application with various features that make it easier for the public to apply for licensing services.
\end{abstract}

Keyword: Public Service, E-government, LAPERON

\section{PENDAHULUAN}

Menurut Richardus E. Indrajit e-government adalah penggunaan ICT (Information, Communication, Techonology) untuk meningkatakan hubungan antara pemerintah dengan pihak lainnya (Indrajit, 2004). McClure juga berpendapat bahwa E-government merupakan pemanfaatan teknologi oleh pemerintah, khususnya aplikasi berbasis web via internet (web-based internet 
application) untuk meningkatkan akses dan pengiriman informasi pemerintah dan layanan kepada warga negara, mitra bisnis, karyawan, lembaga lain, dan entitas pemerintah. E-government berpotensi membantu membangun hubungan yang baik antara pemerintah dan publik dengan menciptakan interaksi yang lebih mudah, efektif, dan lebih efisien dengan warga masyarakat (McClure, 2000). Secara umum, e-government diartikan sebagai pemanfaatan teknologi informasi dan komunikasi dalam penyelenggaraan pemerintahan untuk meningkatkkan kinerja dan hubungan antar pemerintah dengan pihak lain. E-government di Indonesia dimulai sejak adanya Intruksi Presiden No. 6 Tahun 2001 tentang Telematika (Telekomunikasi, Media, dan Informatika) yang menyatakan bahwa aparat pemerintah harus menggunakan teknologi informatika untuk mendukung pelaksanaangood governance.

Pelaksanaan E-government bertujuan untuk meningkatkan kemampuan penyediaan pelayanan publik yang prima pada setiap lembaga atau instansi pemerintahan khususnya pada lembaga yang memberikan layanan publik secara langsung kepada masyarakat. Untuk melaksanakan penerapan E-government yang baik diperlukan adanya komitmen yang besar dari pemerintah dalam membangun akses terhadap pemanfaatan teknologi komunikasi dan informasi, sehingga dapat dengan mudah dijangkau oleh masyarakat. Pemerintah sebagai bagian dalam birokrasi memiliki fungsi utama yaitu menyediakan pelayanan, menyelenggarakan pembangunan, dalam menjalankan tata kelola pemerintahan untuk menyusun dan merangkai masyakarat, seraya menciptakan ketentraman serta keteraturan yang berorientasi pada kesejahteraan masyarakatnya.

Untuk menyokong kesuksesan penerapan E-government, pemerintah pada tahun 2003 mengeluarkan beberapa panduan, antara lain Panduan Pembangunan Infrastruktur Portal Daerah, Pembangunan Manajemen Sistem Dokumen Elektronik Pemerintah, Panduan Penyusunan Rencana E-government Lembaga, Pedoman Penyelenggaraan Diklat ICT dalam menunjang E-government, Pedoman tentang Penyelenggaraan Situs Web Pemerintahan Daerah. Kemudian, diperkuat dengan dikeluarkan Inpres No. 3 Tahun 2003 perihal kebijakkan dan strategi pengembangan $E$-government pada pemerintahan pusat maupun daerah. Yang dilengkapi dengan panduan yang dikeluarkan pada tahun 2004 meliputi: standar 
mutu dan jangkauan pelayanan serta pengembangan aplikasi (E-service), kebijakan tentang kelembagaan, otorisasi, informasi dan keikutsertaan swasta dalam kebijakan penyelenggaraan pemerintahan yang baik dan manajemen perubahan, panduan pelaksanaan proyek dan penganggaran E-government, dan aplikasi E-government pada pemerintah pusat dan daerah. Selain itu, pemerintah juga pada tahun 2006 telah membentuk Dewan Teknologi Komunikasi dan Informasi Nasional melalui Keppres No. 20 Tahun 2006 yang bertugas dalam mempercepat pelaksanaan E-government.

Menurut Undang-Undang Nomor 23 Tahun 2014 perihal Pemerintahan Daerah. Disebutkan bahwa peran pemerintah daerah adalah untuk mempercepat terwujudnya kesejahteraan masyarakat dan meningkatkan daya saing daerah melalui peningkatan pelayanan, pemberdayaan masyarakat, keikutsertaan peran masyarakat, dan peningkatan daya saing daerah dengan memperhatikan prinsip demokrasi, keadilan, pemerataan, dan kekhususan suatu daerah. Kebijakan ini sejalan dengan diberlakukannya Undang-Undang Nomor 25 Tahun 2009 tentang Pelayanan Publik yang menengaskan bahwa penyelenggaraan pelayanan ppublik harus menjamin terselengaraanya pelayanan publik yang berkualitas sesui dnegan prinsip umum pemerintahan Daerah.

Saat ini wajah pelayanan publik sudah lebih baik. Pada beberapa tahun belakangan ini upaya pengembangan penerapan E-government sedang giat-giatnya dilakukan oleh pemerintah baik pusat maupun daerah. Baik pada kementerian, lembaga pemerintahan non kementerian, pemerintah provinsi, pemerintah kota, pemerintah kabupaten dalam memenfaatkan penggunaan E-government pada susunan tata kelola pemerintahannya. Pengembangan penerapan pemanfaatan $E$ government sebagian besar telah berada pada tahap pengembangan aplikasi $E$ government berupa penyediaan website, layanan informasi, dan aplikasi-aplikasi digital lainnya yang menunjang proses pemerintahan, terlebih lagi pada sektor pelayanan publik. Perubahan pemerintahan yang konvensional atau traditional government ke arah Elektronic Government ( E-government) menjadi suatu topik kebijakan publik yang sedang hangat diperbincangkan dewasa ini. Melalui penerapan E-government pada birokrasi pemerintahan mengantikan sistem-sistem lama yang dirasa tidak sesuai lagi bagi kebutuhan masyarakat. Misalnya, untuk 
menerima suatu layanan publik pada pemerintahan dahulu mengharuskan masyarakat untuk mengantri cukup lama untuk satu layanan yang sederhana. Akan tetapi dengan penerapan konsep E-government antrian-antrian pada layanan publik konvensional sebagian besar tidak terjadi lagi. Selain itu, pelaksanaan Egovernment juga bertujuan untuk mendukung tata kelola pemerintahan yang baik. Penerapan teknologi pada birokrasi pemerintahan memungkinkan adanya transparansi pelaksanaan kebijakan dimana masyarakat dapat dengan mudah mengakses informasi-informasi yang relevan. Sehingga hal ini juga dapat menurunkan potensi tindak pidana korupsi pada birokrasi pemerintahan. Selain daripada itu E-government juga diharapkan dapat meningkatkan partisipasi publik dalam proses pengambilan keputusan atau kebijakan yang dikeluarkan oleh pemerintah.

Di Provinsi Bali, khususnya pada Kabupaten Badung telah dilaksanakan sejak tahun 2012 dengan dikeluarkannya Peraturan Bupati Badung Nomor 82 Tahun 2012 tentang Rencana Detail Sistem Informasi Pemerintah Kabupaten Badung yang kemudian pada tahun 2013 diawali dengan penerapan Online Sistem Pelaporan Transaksi Usaha Wajib Pajak Hotel, Wajib Pajak Restoran dan Pajak Hiburan sesuai Peraturan Bupati Nomor 56 Tahun 2013 pada Badan Pendapatan Daerah Kabupaten Badung. Sejak tahun 2013 pemerintahan daerah Badung terus berupaya dalam mengembangkan sistem pemerintahan berbasis elektroniknya. Penerapan E-Government pun telah dilakukan di hampir seluruh Susunan Kelembagaan Pemerintah Daerah (SKPD) Kabupaten Badung, khusunya pada dinas-dinas sektoral yang memberikan layanan pada publik dengan dibangunnya website di masing-masing SKPD. Dalam kanal-kanal website tersebut masyarakat dapat mengetahui bagaimana struktur organisasi di masing-masing lembaga/instansi hingga pelayanan apa saja yang dilayani oleh lembaga/instasi tersebut.

Kabupaten Badung sendiri memiliki cukup banyak peluang pada sektor perdagangan, pariwisata, dan perindustrian. Peluang atau opportunity tersebut memungkinkan banyaknya masyarakat di Kabupaten Badung maupun warga asing atau pihak swasta untuk melakukan perizinan setiap tahunnya. Besarnya peluang ini dapat dimanfaatkan oleh pemerintahan daerah Kabupaten Badung untuk 
membangun daerahnya dan mensejahterakan masyarakat di daerah Kabupaten Badung. Tentunya, untuk meningkatkan animo tersebut pemerintah daerah harus menyediakan fasilitas yang dapat mempermudah masyarakat dalam urusan perizinan. Umumnya, lamanya pengurusan izin yang berlbelit-belit sampai dengan tidak adanya kejelasan informasi terkait proses perizinan mulai dari kapan mengajukan perizinan, syarat-syarat yang diperlukan dalam proses perizinan, hingga pada alur dalam memperoleh perizinan acap kali menjadikan masyrakat ataupun investor di Kabupaten Badung enggan untuk membuat surat perizinan. Untuk mengatasi hal tersebut Pemerintahan Daerah Kabupaten Badung menyediakan suatu lembaga perizinan yang terpadu secara satu pintu, sehingga memudahkan masyrakat dalam mengurus suatu perizinan dalam satu portal website yang dapat diakses secara online dan mandiri. Dinas Tersebut ialah Dinas Penanaman Modal dan Pelayanan Terpadu Satu Pintu.

Pemerintahan Daerah Kabupaten Badung sebagai salah satu bagian dari Pemerintahan Republik Indonesia juga mengupayakan proses percepatan pertumbuhan ekonomi masyarakatnya. Pemerintahan Kabupaten Badung menyediakan layanan perizinan yang bersifat terpadu dan satu pintu, dengan dibentuknya Dinas Penanaman Modal dan Pelayanan Terpadu Satu Pintu (DPMPTSP) Kabupaten Badung. Dinas Penanaman Modal dan Pelayanan Terpadu Satu Pintu (DPMPTSP) Kabupaten Badung ialah lembaga yang memegang peranan dan fungsi strategis pada bidang penyelenggaraan perizinan dan penanamam modal di Kabupaten Badung, yang dibentuk berdasarkan pada Peraturan Daerah Kabupaten Badung Nomor 08 Tahun 2016 perihal pembentukan dan susunan Perangkat Daerah Kabupaten Badung. DPMPTSP Kabupaten Badung merupakan salah satu Dinas di lingkungan pemerintahan daerah Kabupaten Badung yang melakukan pemanfaatan dan penerapan teknologi komunikasi dan informasi pada pelayanan publiknya. Pelaksanaan E-government di Dinas Penanaman Modal dan Pelayanan Terpadu Satu Pintu dapat dilihat dari adanya berbagai inovasi sistem yang disediakan oleh DPMPTSP Kabupaten Badung ini. Salah satunya adalah inovasi program "Laperon" (Layanan Perizinan Online) yang disediakan oleh Dinas Penanaman Modal dan Pelayanan Terpadu Satu Pintu (DPMPTSP). "Laperon” merupakan layanan perizinam online yang 
dibangun secara mandiri untuk mempermudah masyarakat dalam melakukan proses pengurusan izin dan non izin yang menjadi kewenangan pemerintah Kabuapaten Badung yang dapat diakses melalui website resmi DPMPTSP Kabupaten Badung. Terdapat 122 jenis perizinan dan non-perizinan yang dapat diakses secara daring atau online yang menjadi kewenangan Pemerintahan Kabupaten Badung.

Berdasarkan permasalahan diatas, penulis tertarik meneliti perihal Pengembangan Pelayanan Publik Berbasis E-government Dalam Program Layanan Perizinan Online (Laperon) di Dinas Penanaman Modal dan Pelayanan Terpadu Satu Pintu (DPMPTSP) di Kabupaten Badung. Penulis ingin mendalami dengan adanya pelayanan berbasis E-governmnet apakah mampu memberikan pelayanan publik yang lebih mudah, murah, cepat, dan tepat sehingga pelayanan publiknya lebih efektif dan efisien.

\section{TINJAUAN TEORITIS}

\section{E-Government}

Menurut Richardus E. Indrajit, e-government adalah penggunaan ICT (Information, Comunication, Technology) untuk meningkatkan hubungan antara pemerintah dengan pihak-pihak lain (Indrajit, 2004). The World Bank memberikan pendefinisian tentang e-government sebagai upaya pemanfaatan dan pendayagunaan telematika untuk meningkatkan efisiensi dan cost-effective pemerintahan, memberikan berbagai jasa pelayanan kepada masyarakat secara lebih baik, menyediakan akses informasi kepada publik secara lebih luar, dan menjadikan penyelenggaraan pemerintahan lebih bertanggung jawab (accountable) serta transparan kepada masyarakat. Berdasarkan pengertian tersebut, penerapan e-government merupakan penggunaan teknologi informasi oleh semua pihak baik di wilayah kekuasaan legislative, yudikatif maupun eksekutif terkait dengan informasi mengenai kegiatan pemerintahan dan pelayanan masyarakat dalam menyediakan partner bisnis dan akses informasi kepada publik secara lebih luas.Pada dasarnya E-Government adalah pemanfaatan teknologi informasi untuk meningkatkan hubungan antara pemerintah dan pihakpihak lain. Di dalam konsep E-Government dikenal pula empat jenis klasifikasi, 
yaitu: Government to Citizens, Government to Business, Government to Government, dan Government to Employees.

Berdasarkan hasil kajian dan riset dari Harvard JFK School of Government, untuk menerapkan konsep digitalisasi pada sektor publik, ada tiga elemen sukses yang harus dimiliki dan diperhatikan. Masing-masing elemen sukses tersebut adalah:

1. Support, yang mendukung dalam pengembangan e-government, antara lain:

a. Political Will, sejauhmana dukungan Pemerintah dalam kemauan pemerintah dalam mengembangkan e-government

b. Kontinyuitas, keberlanjutan penerapan e-government yang mencakup perencanaan e-government di kedepannya.

c. Sosialisasi, mengetahui bagaimana pemerintah dalam mensosialisasikan pengembangan e-government tersebut.

2. Capacity, merupakan kemampuan pemerintah dalam mewujudkan $e$ government, antara lain:

a. Sumber daya manusia yang berkompeten dan memiliki keahlian dalam mengelola dan mengakses teknologi informasi agar penerapan $e$ government sesuai yang diharapkan.

b. Sumber daya finansial, untuk mengetahui anggaran yang ditetapkan dan pengalokasian dana dalam pengembangan e-government.

c. Infrastruktur, melihat bagaimana ketersediaan infrastruktur teknologi

3. Value, keuntungan manfaat yang diperoleh dengan adanya pengembangan $e$ government tersebut, khususnya manfaat yang akan diperoleh masyarakat dengan adanya e-government.

\section{Good Governance}

Menurut Sedarmayanti (2004:3) good governance sebagai nilai yang menjungjung tinggi keinginan atau kehendak rakyat dan dapat meningkatkan kemampuan rakyat dalam pencapaian tujuan (nasional) kemandirian, pembangunan berkelanjutan dan keadilan sosial serta pemerintah yang efektif dan efisien dalam pelaksanaan tugasnya untuk mencapai tujuan tersebut. 
Menurut Bank Dunia yang dikutip Wahab (2002:34) menyebut Good Governance adalah suatu konsep dalam penyelenggaraan manajemen pembangunan yang solid dan bertanggung jawab sejalan dengan demokrasi dan pasar yang efisien, penghindaran salah alokasi dan investasi yang langka dan pencegahan korupsi baik secara politik maupun Administrasi, menjalankan disiplin anggaran serta penciptaan legal framework bagi tumbuhnya aktivitas kewiraswastaan. Selain itu Bank Dunia juga mensinonimkan Good Governance sebagai hubungan sinergis dan konsturktif diantara Negara, sektor swasta dan masyarakat.Dari berbagai hasil yang dikaji Lembaga Administrasi Negara (LAN) menyimpulkan ada sembilan aspek fundamental dalam perwujudan good governance, yaitu:

1. Partisipasi (Participation): Setiap warga Negara mempunyai suara dalam formulasi keputusan, baik secara langsung maupun intermediasi institusi legitimasi yang mewakili kepentingannya. Partisipasi seperti ini dibangun atas dasar kebebasan berasosiasi dan berbicara secara berpartisipasi secara konstruktif

2. Penerapan Hukum (Fairness): Kerangka hukum harus adil dan dilaksanakan tanpa pandang bulu, terutama hukum untuk hak azasi manusia.

3. Transparansi (Transparency): Transparansi dibangun atas dasar kebebasan arus informasi secara langsung dapat diterima oleh mereka yang membutuhkan. Informasi harus dapat dipahami dan dapat dimonitor.

4. Responsivitas (Responsiveness): Lembaga-lembaga dan proses-proses kelembagaan harus mencoba untuk melayani setiap stakeholders.

5. Orientasi (Consensus Oreintation): Good Governance menjadi perantara kepentingan yang berbeda untuk memperoleh pilihan terbaik bagi kepentingan yang lebih luas, baik dalam hal kebijakan-kebijakan maupun prosedur-prosedur.

6. Keadilan (Equity): Semua warga Negara, baik laki-laki maupun perempuan mempunyai kesempatan untuk meningkatkan ataupun menjaga kesejahteraan mereka dan terlibat di dalam pemerintahan. 
7. Efektivitas (Effectivness): Proses-proses dan lembaga-lembaga menghasilkan sesuai dengan apa yang telah digariskan dengan menggunakan sumber-sumber yang tersedia sebaik mungkin.

8. Akuntabilitas (Acoountability): Para pembuat keputusan dalam pemerintahan, sektor swasta dan masyarakat sipil (civil society) bertanggungjawab kepada publik dan lembaga-lembaga stakeholders. Akuntabilitas ini tergantung pada organisasi dan sifat keputusan yang dibuat, apakah keputusan tersebut untuk kepentingan internal atau eksternal organisasi.

9. Strategi visi (Strategic vision): Para pemimpin dan publik harus mempunyai perspektif good governance dan pengembangan manusia yang luas dan jauh kedepan sejalan dengan apa yang diperlukan untuk pembangunan semacam ini

\section{Pelayanan Publik}

Istilah pelayanan berasal dari kata "layan" yang artinya menolong menyediakan segala apa yang diperlukan oleh orang lain untuk perbuatan melayani. Pada dasarnya setiap manusia membutuhkan pelayanan, bahkan secara ekstrim dapat dikatakan bahwa pelayanan tidak dapat dipisahkan dengan kehidupan manusia (Sinambela, 2010:3). Ratminto (2005) mendefinisikan bahwa Pelayanan publik atau pelayanan umum dapat didefenisikan sebagai segala bentuk jasa pelayanan, baik dalam bentuk barang publik maupun jasa publik yang pada prinsipnya menjadi tanggung jawab dandilaksanakan oleh 10 instansi pemerintah di pusat, didaerah, dan dilingkungan Badan Usaha Milik Negara atau Badan Usaha Milik Daerah, dalam rangkaupaya pemenuhan kebutuhan masyarakat maupun dalam rangkapelaksanaan ketentuan peraturan perundangundangan. Terdapat 3 unsur penting dalam pelayanan publik, yaitu:

1. Organisasi pemberi (penyelenggara) pelayanan yaitu Pemerintah Daerah

2. Penerima layanan (pelanggan) yaitu orang atau masyarakat atau organisasiyang berkepentingan 
3. Kepuasan yang diberikan dan/atauditerima oleh penerima layanan (pelanggan).

\section{Kebijakan Publik}

Kebijakan pada umumnya selalu berkaitan pada "publik dan masalahmasalahnya”. Kebijakan juga membahas bagaimana isu-isu dan persoalan dapat disusun (contructed), serta didefinisikan bagaimana semua persoalan tersebut dapat diletakan dalam agenda kebijakan. Secara konseptual kebijakan publik dapat dilihat dari Kamus Administrasi Publik Chandler dan Pleno seperti dikutip dalam Pasolong (2007:38-39) mengatakan bahwa kebijakan publik adalah pemanfaatan yang strategis terhadap sumber-sumber daya yang ada untuk memecahkan masalah publik dalam pemerintahNugroho dalam Laksomono (2019:24) menjelaskan bahwa kebijakan publik adalah keputusan politik yang dibuat oleh lembaga publik. Lembaga publik adalah lembaga yang didanai dari dana/uang publik, yaitu uang yang dipungut secara kolektif dari publik, baik berupa pajak, retribusi, atau pungutan-pungutan lain yang ditetapkan secara formal.

Berdasarkan beberapa definisi tersebut, penulis dapat menyimpulkan bahwa kebijakan publik dibuat berdasarkan suatu permasalahan yang dapat diselesaikan dengan membahas setiap persoalan kemudian disusun menjadi sebuah agenda kebijakan untuk mencapai tujuan dan sasaran tertentu yang telah ditetapkan. Maksud tujuan dan sasaran kebijakan publik dibuat adalah untuk memecahkan masalah publik yang tumbuh dan berkembang di masyarakat. Namun, tidak semua masalah publik dapat dijadikan sebuah kebijakan publik, karena masalah tersebut memiliki banyak macam, variasi dan intensitasnya. Hanya masalah publik yang dapat menggerakan orang banyak untuk ikut memikirkan dan mencari solusi yang bisa menghasilkan sebuah kebijakan publik

Dalam pandangan Ripley dalam Taufiqurokhman (2014), tahapan kebijakan publik digambarkan sebagai berikut:

1. Tahap Penyusunan Agenda

Dalam penyusunan agenda kebijakan terdapat tiga kegiatan yang perlu dilakukan yakni; 
a. Membangun persepsi di kalangan stekholders bahwa sebuah fenomena benar-benar dianggap sebagai masalah. Sebab bisa jadi suatu gejala oleh sekelompok masyarakat tertentu dianggap masalah, tetapi oleh sebagian masyarakat yang lain atau elite politik bukan dianggap sebagai masalah;

b. Membuat batasan masalah;

c. Memobilisasi dukungan agar masalah tersebut dapat masuk dalam agenda pemerintah yang dilakukan dengan cara mengorganisir kelompokkelompok yang ada dalam masyarakat, kekuatan-kekuatan politik, publikasi melalui media massa, dan sebagainya.

2. Tahap Formulasi dan Legitimasi Kebijakan

Pada Tahap Formulasi dan Legitimasi Kebijakan, analisis kebijakan perlu mengumpulkan dan menganalisis informasi yang berhbungan dengan masalah yang bersangkutan, kemudian berusaha mengembangkan alternatif - alternatif kebijakan, membangun dukungan dan melakukan negosiasi, sehingga sampai pada sebuah kebijakan yang dipilih.

3. Tahap Implementasi Kebijakan Publik

Pada tahap ini perlu dukungan sumberdaya, dan penyusunan organisasi pelaksana kebijakan. Dalam proses implementasi sering ada mekanisme insentif dan saksi agar implementasi suatu kebijakan berjalan dengan baik.

4. Tahap Evaluasi Kebijakan

Tahap selanjutnya adalah evaluasi terhadap implementasi, kinerja, dan dampak kebijakan. Hasil evaluasi ini bermanfaat bagi penentuan kebijakan baru dimasa yang akan datang, agar kebijakan yang akan datang lebih baik dan lebih berhasil.

\section{METODOLOGI PENELITIAN}

Penelitian ini menggunkaan metode deskriptif. Key informan dalam hal ini adalah Kepala Dinas Penanaman Modal dan Pelayanan Terpadu Satu Pintu (DPMPTSP) Kabupaten Badung. Sedangkan informan adalah masyarakat Badung yang penah menggunakan LAPERON dalam penerimaan layanan publik.

Hasil dari pengumpulan data kemudian di analisis secara deskriptif lalu penggabungan data dilakukan guna menambahkan hasil karya disertai dengan 
konsep maupun teori yang dikembangkan dalam penelitian ini. Selanjutnya teknik analisis dalam penelitian ini bersifat induktif dan lebih menekankan pada makna daripada generalisasi (Sucipto, 2012).

\section{HASIL, PENELITIAN DAN PEMBAHASAN}

Electronic Government atau E-governmrnt merupakan salah satu model pemerintahan yang melakukan pemanfaatan terhadap teknologi komunikasi dan informasi, dimana hampir pada seluruh kegiatan pemerintahannya berlandasakan pada kekuatan teknolgi digital. Kegiatan pemerintahan tersebut baik berupa kegiatan administrasi, pelayanan kepada publik, controlling, ataupun pengendalian sumber daya yang dimiliki oleh organisasi atau lembaga birokrasi terkait, keuangan, pajak dan retribusi, sumber daya manusia (pegawai/staf) yang dikendalikan dalam satu sistem. E-government.

Pemerintahan melalui pemanfaatan teknologi komunikasi dan informasi dalam birokrasi atau pemerintahan publik tidak dapat dihindari lagi. Tuntutan dalam meningkatkan kualitas pelayanan publik serta meningkatkan partisipasi aktif dalam memberikan informasi bagi masyarakat yang dituntut lebih efektif. Mengakibatkan penerapan pemerintahan berbasis digital atau E-government semakin memiliki kedudukan penting terhadap pengambilan keputusan. Pemerintahan yang dilakukan secara konvensional atau tradisional yang indentik dengan papper-based administration mulai ditinggalkan. Konsep E-government menjadi suatu perkembangan yang baru untuk meningkatkan layanan publik yang dilakukan dengan melakukan pemanfaatan teknologi komunikasi dan informasi yang memungkinkan terjadinya layanan publik yang lebih transparan, bertanggung jawab, efektif, serta efisien.

Model E-government merupakan bentuk pengoptimalan terhadap pemanfaatan teknologi komunikasi dan informasi dalam bentuk aplikasi sebagai upaya meningktkan kegiatan organisasi di sektor publik. E-government juga dapat membantu dalam mengoptimalkan mekanisme hubungan baru yang memberikan peluang bagi keharmonisan hubungan antara pemerintah dnegan masyarakat serta kalangan lain yang berkepentingan dengan maksud memningkatkan kualitas pelayanan publik. Melalui penerapan E-government dapat membantu menghemar 
biaya, waktu dan proses yangpanjang dan berbelit-belit, dan ketidaknyamanaan dalam penyediaan layanan publik. Di Indonesia pelaksanaan E-government sendiri telah dilaksanakan pada beberapa daerah di Indonesia dengan tingkat keberagaman yang bervariasi. Usaha pencapaian tujuan akhir dari pelaksanaan konsep E-government harus memperhatikan dua hal, yaitu proses transformasi elekttronik dalam organisasi serta dampak-dampak yang mungkin ditimbulkannya. Makna E-government di Indonesia merujuk pada pemanfaatan komputer dalam tata cara pelayanan publik yang diselenggarakan oleh birokrasi pemerintahan. Perubahan traditionalgovernment menjadi E-government harus semakin ditingkatkan dengan mempersiapkan serta mebangun infrastrukturinfrastruktur yang menunjang pelaksaanan E-government di lingkungan pemerintahan, misalnya akses internet, kemampuan aparatur negara, hardware dan software yang memadai, dan sebagainya.

Inovasi penerapan $E$-government pada sektor pelayanan publik di pemerintahan daerah Kabupaten Badung salah satunya dapat dilihat dari program LAPERON (Layanan Perizinan Online) yang dibuat secara mandiri oleh Dinas Pelayanan Terpadu Satu Pintu (DPMPTSP) Kabupaten Badung yang bekerja sama dengan Balai Sertifikasi Elektronik. Bali Dwipa, SRIKOM Bali, Mal Pelayanan Publik Kabupaten Badung, dan Zona Integritas untuk memudahkan masyarakat dalam mengakses layanan publik dalam hal ini perizinan, secara mudah, murah, dan cepat melalui satu website yang telah disediakan oleh DPMPTSP Kabupaten Badung. Melalui program LAPERON ini masyarakat dapa mengakses setidaknya 122 jenis perizinan dan non-perizinan yang dapat diakses secara daring atau online yang menjadi kewenangan Pemerintahan Kabupaten Badung. Masyarakat sendiri dapat mengakses program ini secara langsung melalui website LAPERON, yaitu (Layanan Perizinan Online (LAPERON) Kabupaten Badung (badungkab.go.id)) atau melalui website resmi DPMPTS Kabupaten Badung pada lama pencarian (DPMPTSP Beranda Website Resmi (badungkab.go.id)). Program LAPERON ini juga dapat diakses dengan mengistal aplikasi LAPERON Mobile pada play store untuk pengguna android.

Pengembangan inovasi program layanan publik LAPERON ini terus diupayakan oleh Dinas Penanaman Modal dan Pelayanan Terpadu Satu Pintu 
untuk dapat memberikan pelayanan publik secara maksimal dan dapat mmpermudah masyarakat dalam mengakses layanan publik khususnya pada bidang pengurusan perizinan. Di mana sebelum dilaksanakannya konsep digitalsisasi atau E-governmnet ini pengurusan perizinan pada sektor pelayanan publik indentik dan erat kaitanyya dnegan proses yang lama, biaya yang tinggi, dan banyaknya praktik pungli yang menghiasi proses pelayanan pengurusan perizinan. Dengan adanya LAPERON ini pemerintah Kabupaten Badung berusaha menerapkan lingkungan kepemerintahan yang berintegritas dan bebas dari pungli. Melalui pengembangan sistem LAPERON ini dilakukan penataan sistem manajemen dan proses kerja dilingkungan Dinas Penanaman Modal dan Pelayanan Terpadu Satu Pintu (DPMPTSP) Kabupaten Badung yang melakukan pengoptimalisasian penggunaan teknologi komunikasi dan informasi. Berdasarkan sifat transaksi informasi dan pelayanan publik dalam pengurusan perizinan oleh DPMPTSP Kabupaten Badung dilakukan pengembangan terhadap E-government yang dilaksanakan melalui beberapa tahapan, yaitu

1. Persiapan

Pada tahap ini Dinas Penanamam Modal dan Pelayanan Terpadu Satu Pintu (DPMPTSP) Kabupaten Badung mempersiapakan program LAPERON dengan pembuatan situs web dan aplikasi yang dapat diunduh pada android yang menyediakan berbagai macam jenis layanan perizinan yang dapat diakses secara mandiri oleh masyarakat yang dapat disesuaikan dengan kebutuhan masyarakat itu sendiri. Selain itu Dinas Penanaman Modal dan Pelayanan Terpadu Satu Pintu juga telah melakukan sosialisasi-sosialisasi terkait penggunaan tan cara-cara mengakses atau menggunakan LAPERON baik pada website atau mobile.

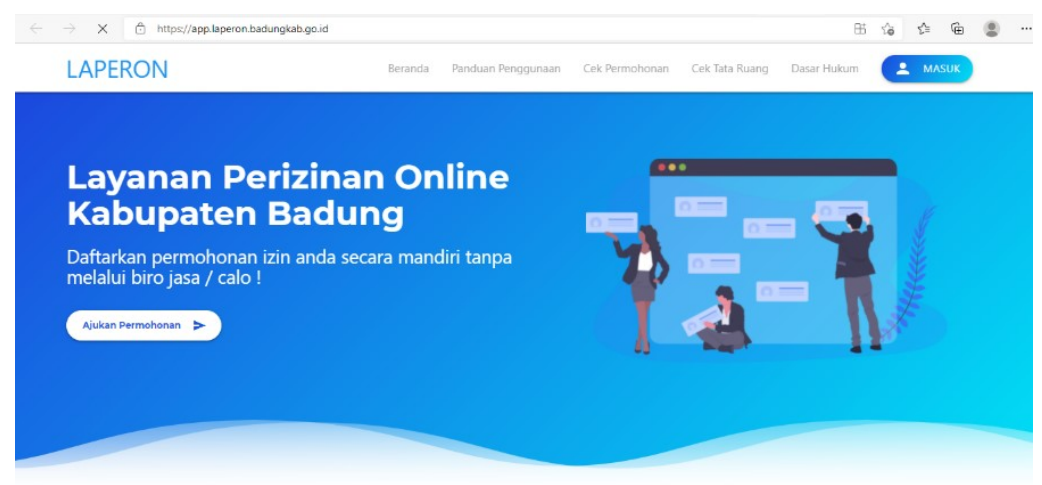


Gambar 1. Tampilan halaman awal website LAPERON(Sumber:

https://dpmptsp.badungkab.go.id)

\section{Pematangan}

Dibangunnya website dan aplikasi saja tidak cukup untuk dapat memberikan layanan yang prima pada masyarakat. Diperlukan adanya pengembangan yang matang agar nantinya inovasi program yang dicanangkan benar-benar dapat dipahami dan digunakan oleh masyarakat dengan mudah, yang dapat memberikan pengalaman yang baik dalam penerima layanan perizinan secara online ini. Untuk itu, DPMPTS Kabupaten Badung mengemas website serta aplikasi mobile LAPERON dengan interaktif agar dapat mempermudah masyarakat dalam menggunakannya. Dalam aplikasi LAPERON masyarakat tidak hanya dapat melakukan pengajuan izin tetapi juga dapat melakukan tracking terhadap pengajuan yang telah dilakukan. Dengan begitu masyarakat tidak perlu khawatir dan cemas dalam memperhitungkan kapan pengajuan mereka selesai, dikarenakan dalam LAPERON masyarakat diberikan pemberitahuan atas kemajuan dari izin yang diajukan. Kemudian dalam LAPERON masyarakat juga dapat mengajukan permohonan layanan publik baik yang bersifat perizinan maupun non-perizinan seperti pembayaran retibusi dan lain-lain.

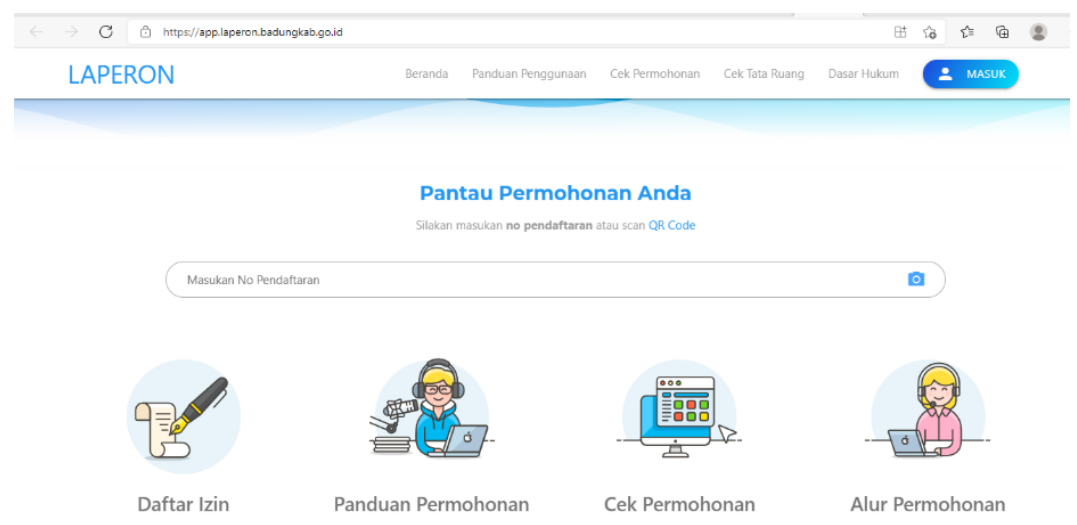


Gambar 2. Fitur-fitur dalam LAPERON(Sumber:

https://dpmptsp.badungkab.go.id)

3. Evaluasi

Pada dasarnya berbagai kebiajakan ataupun inovasi program layanan publik yang dikeluarkan pemerintah adalah untuk masyarakat. Kepuasan masyarakatlah yang menjadi tolak ukur keberhasilan atas program dan kebijakan yang dikeluarkan tersebut. Untuk itu dalam setiap inovasi program layanan publik penting untuk dilakukan survei terhadap kepuasan masyarakat dalam menerima layanan publik tersebut. Hal Ini juga telah tertuang dalam Undang-Undang Republik Indonesia Nomor 25 Tahun 2000 perihal Program Pembangunan Nasional (PROPENAS) dimana diperlukan adanya penyusunan terhadap indeks kepuasan masyarakat sebagai pengukur dalam memberikan penilaian terhadap pelayanan publik yang masih perlu perbaikan dan menjadi pendorong seluruh unni penyelenggara pelayanan publik dalam terus berupaya menungkatkan kualitas pelayananya.

Dinas Penanaman Modal dan Pelayanan Terpadu Satu Pintu (DPMPTSP) Kabupaten Badung juga berupaya untuk terus meningkatkan kualitas pelayanan publiknya melalui aplikasi LAPERON dengan terus melakukan pengukuran terhadap persepsi dan kepuasan masyarakat untuk dapat mengetahui sejauhmana LAPERON ini mempermudah proses perizinan. Hingga Agustus 2021 tercatat sebanyak. 28.266 pemohon yang telah mengajukan permohonan baik perizinan maupun non-perizinan pada aplikasi LAPERON dengan jumlah sebanyak 19.240 permohonan yang telah selesai dan sebanya 2.323 permohonan yang masih di dalam proses. Selain itu, DPMPTSP Kabupaten Badung juga melakukan pengukuran terhadap index kepuasan masyarakat terhadap aplikasi LAPERON ini. Dimana dalam website serta aplikasi mobile LAPERON masyarakat dapat berpartisipasi secara aktif dalam mengisi survey Elektronik. Pada Agustus 2021 dilansir dari aplikasi resmi LAPERON tercatat index kepuasan masyarakat terhadap LAPERON yaitu sebesar 91.00 dengan jumlah responden sebanyak 1676 
responden. Artinya, Masyarakat merasa puas dan terbantu dengan adanya aplikasi layanan perizinan secara online atau LAPERON.

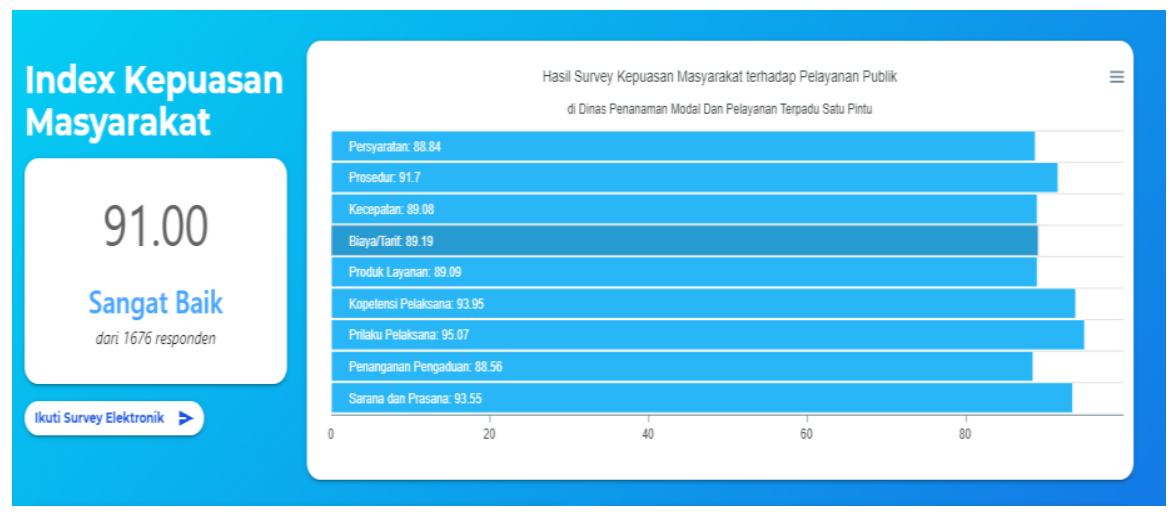

Gambar 3. Index Kepuasan Masyarakat terhadap Aplikasi LAPERON(Sumber:

https://dpmptsp.badungkab.go.id)

\section{KESIMPULAN}

Konsep digitalisasi atau yang dikenal sebagai E-government tidak dapat dihindari lagi. Kemajuan teknlogi yang semakin maju tentunya juga memajukan dan merubah standar atas layanan publik yang diharapkan masyarakat dari pemerintah. Dengan kemajuan teknologi masyarakat mengharpakan mendapatkan pelayanan publik yang cepat, murah, dan mudah. Untuk menjawab kebutuhan masyarakat Dinas Penanaman Modal dan Pelayanan Terpadu Satu Pintu (DPMPTSP) Kabupaten Badung sebagai salah satu dinas di lingkungan daerah Kabupaten yang memberikan berbagai jenis pelayanan publik, salah satunya pada bidang perizinan. Pelayanan perizinan dahulu erat kaitannya dengan proses yang panjang, lama, bertele-tele, mahal, hingga dipenuhi dengan praktik pungli dalam pelaksanaanya. Kini, layanan perizinan khususnya di Kabupaten Badung dikelola secara terpadu oleh DPMPTSP Kabupaten Badung. DPMPTSP Kabupaten Badung mengeluarkan sebuah inovasi program yang bertujuan untuk mepermudah pengurusan izin bagi masyarakat, pelaku usaha, maupun pihak swasta untuk dalam mendaftarkan atau mengajukan perizinan yaitu, aplikasi atau website LAPERON ( Layanan Perizinan Online). Pengembangan Layanan Perizinan Online atau LAPERON ini terus digalangkan oleh DPMPTSP Kabupaten Badung 
dengan melengkapi sistem LAPERON dengan fitur-fitur yang memberikan kemudahan bagi masyarakat dalam menggunakannya, seperti fitur tracking permohonan yang dapat memberitahukan sudah sejauh mana pengajuan yang telah kita lakukan di proses, kemudian terdapat pula 122 jenis perizinan dan nonperizinan yang dapat diakses secara daring atau online yang menjadi kewenangan Pemerintahan Kabupaten Badung. Selain itu, LAPERON juga dilengkapi dnegan informasi perihal index kepuasan masyarakat untuk mengukur kepuasan masyarakat pengguna LAPERON dimana masyarakat dapat berpatisipasi langsung dalam mengisi survei kepuasan masyarakat.

\section{DAFTAR PUSTAKA}

Indrayani, E. (2016). Jatinangor: Institut Pemerintah Dalam Negeri

Alamsyah, Anggriani, 2016. Pekembangan Paradigma Administrasi Publik (New Public Administration, New Public Management dan New Public Service). Jurnal Politik Profetik, Vol. 4, no. 2, hh. 172-199. PERKEMBANGAN PARADIGMA ADMINISTRASI PUBLIK New ... (uin-alauddin.ac.id), diakses 25 November 2020.

Arif, M.S., Larasati, E., \& Rihandoyo, 2013. Analisis Pengembangan Electronic Government Melalui Penyelenggaraan Website di Kabupaten Kudus.ANALISIS PENGEMBANGAN ELECTRONIC GOVERNMENT ... (undip.ac.id), diakses 25 November 2020.

Aristanto, D.B, 2017. Pengaruh Knowledge Sharing Terhadap Individual Innovation Capability dan Kinerja Karyawan (Studi Pada PT. PLN (PERSERO) Unit Induk Pembangunan Sulawesi Utara). Jurnal EMBA. Vol. 5, no. 2, hh. 1539-1545. Pengaruh Knowledge Sharing Terhadap Individual Innovation ... (neliti.com), diakses 26 November 2020.

Maktublo, H, 2020. Pelayanan Perizinan Berbasis Elektronika Online di Dinas Penanaman Modal dan Perizinan Kota Yogyakarta: http://repo.apmd.ac.id/1298/. Diakses pada 14 Agustus 2021

Sudrajat, Setyowati, Sukanto, 2016. Efektivitas Penyelenggaraan E-Government Pada Badan Pelayanan Perizinan Terpadu Kota Malang. Jurnal Administrasi Publik: file://D:/Downloads/1111-7565-1-PB.pdf. Diakses pada 14 Agustus 2021 